УДК 631.417: 631.588

(C) 2015

Чередниченко І. В., асистент кафедри трунтознавства

(науковий керівник - доктор сільськогосподарських наук В. В. Дегтярьов)

Харківський національний аграрний університет ім. В. В. Докучаєва

\title{
ВМІСТ РУХОМИХ ОРГАНІЧНИХ РЕЧОВИН ЗА РІЗНИХ СИСТЕМ УДОБРЕННЯ В УМОВАХ ОРГАНІЧНОГО ЗЕМЛЕРОБСТВА
}

\section{Рецензент - доктор сільськогосподарських наук П. В. Писаренко}

У статті наведені дослідження впливу різних систем удобрення на вміст рухомих органічних речовин чорнозему типового в умовах органічного землеробства. Встановлено, що введення перелогового режиму сприяє суттєвому зростанню частки рухомих органічних речовин у загальному гумусі. Позитивний вплив на вміст рухомих органічних речовин у загальному гумусі має застосування органічної та сидеральноі систем удобрення, а також введення у сівозміну багаторічних трав. Застосування мінеральної системи удобрення викликає збіднення трунту на рухомі органічні речовини.

Ключові слова: трунт, система удобрення, рухомі органічні речовини, гумус, чорнозем типовий.

Постановка проблеми. Сгоров М. А. вказував, що загальноприйняті методи дослідження грунту не показують будь-яких характерних відмінностей між грунтами різного ступеня окультуреності, які мають одне генетичне походження. Він вважав, що легкорухомі органічні речовини, які вилучаються 3 грунту 0,2 н розчином $\mathrm{NaOH}$, можуть бути гарним показником ступеня його окультуреності. Ця думка грунтувалась на тому, що власне цій складовій органічній частині грунту належить величезна роль у живленні рослин, так як саме вона $є$ першоджерелом азотного живлення рослин, з нею, можливо, пов'язано в значній мірі і постачання рослинам фосфорної кислоти, а, можливо, і низки інших суттєво необхідних поживних елементів. Автор вважав, що, перш за все, найбільш рухомій частині гумусу належить визначальна роль у забезпеченні сприятливих умов життя рослин, а не органічній частині грунту загалом [1].

Результати досліджень деяких вчених $[5,8]$ показали, що вміст рухомих органічних речовин чітко відображає культурний стан чорноземів типових Лісостепу України і може бути одним із діагностичних показників їхньої окультуреності. У процесі досліджень цими авторами встановлено прямий зв'язок ступеня рухомості органічних речовин $з$ кількістю внесених у грунт органічних і мінеральних добрив.

Аналіз основних досліджень і публікацій, в яких започатковано розв'язання проблеми. Вивчення та оцінка якості грунтів є найважливішим етапом у встановленні рівня їх родючості. Численними дослідженнями показано, що найголовнішими i загальними критеріями оцінки рівня продуктивності грунту - $\epsilon$ грубизна гумусових горизонтів і запаси гумусу в них. На врожайність сільськогосподарських культур впливає не тільки загальний запас органічних речовин, але і якісний склад гумусу [2]. Численні дослідження свідчать про те, що значним резервом збереження та відтворення гумусу в орних грунтах поряд із грунтозахисними і протиерозійними заходами, розширенням посівів багаторічних трав i впровадженням науково обгрунтованих сівозмін, є органічні і мінеральні добрива $[4,6$, 9]. Однак питання про вплив різних систем удобрення на вміст рухомих органічних речовин чорноземів типових в умовах органічного землеробства досі залишається недостатньо вивченим.

Мета досліджень: вивчення впливу різних систем удобрення на вміст рухомих органічних речовин у чорноземах типових середньосуглинкових в умовах органічного землеробства.

Завдання дослідження:

1) визначити вміст рухомих органічних речовин по варіантам: переліг, контроль (без добрив), органічна система добрив, багаторічні трави (еспарцет третього року використання), сидеральна система добрив, мінеральна система добрив;

2) розрахувати частку рухомих органічних речовин у загальному гумусі чорноземів типових за різних систем удобрень;

3) проаналізувати отримані дані по досліджуваним варіантам.

Методика дослідження. Дослідження проводилися протягом 2008-2014 рр. у виробничих умовах на чорноземі типовому середньосуглинковому ПП «Агроекологія» Шишацького району Полтавської області (підприємство сертифіковано, як органічне господарство, згідно з вимогами 


\section{СІЛЬСЬКЕ ГОСПОДАРСТВО. РОСЛИННИЦТВО}

стандартів постанови Ради СС «ЕС 834/2007», «ЕС 889/2008») та розташованого поряд 3 агрохолдингом «Астарта-Київ», де ведеться інтенсивне використання земельних ресурсів, застосовуються високі дози мінеральних добрив.

Грунт - чорнозем типовий середньосуглинковий на лесовидному суглинку. Грунтовий покрив ділянок однорідний. Зразки відбиралися по варіантам: переліг, контроль (без добрив), органічна система добрив, багаторічні трави (еспарцет третього року використання), сидеральна система добрив, мінеральна система добрив. Індивідуальні зразки відбиралися через кожні 10 см до глибини 50 см у трьохкратній повторності.

Результати дослідження. Проведені дослідження показали, що, як і слід було чекати, найвищий уміст рухомих органічних речовин спостерігається у чорноземі типовому ділянки перелогу (див. табл.). Порівняно з чорноземом контролю тут уміст рухомих органічних речовин по всім досліджуваним шарам грунту в 2,5-4 рази вище. Це пов'язано $з$ тим, що в умовах природної степової рослинності, яка зростає на перелозі протягом 35 років, у грунт надходить щорічно значно більше рослинних решток як надземних, так і кореневих, які $\epsilon$ джерелом утворення «молодого» рухомого гумусу. Цьому сприяють особливі водний, повітряний, тепловий та інші режими грунту, які формуються в умовах природного ценозу. Уведення у сівозміну багаторічних трав сприяє накопиченню рухомих органічних речовин, особливо у 10-30-сантиметровому шарі чорнозему порівняно 3 грунтом контролю. Саме в цьому шарі грунту зосереджена основна маса кореневої системи еспарцету. Протягом трьох років (еспарцет третього року використання) у цьому шарі грунту відбулося накопичення дрібних корінців, які щорічно відмирали і слугували джерелом для новоутворення рухомих органічних речовин. Більш суттєвий вплив на вміст рухомих органічних речовин має органічна система добрив. Чорнозем за органічної системи удобрення містить в 2,1 (шар 0-10 см) - 2,6 (шар 10-20 см) рази більше рухомих органічних речовин порівняно 3 аналогічними шарами чорнозему контролю. Це, насамперед, пов'язано 3 надходженням органічних решток (гною) в поверхневий шар чорнозему. Безполицевий обробіток грунту на глибину 10-12 см сприяє переміщуванню лише верхньої частини профілю грунту. Тому тут більш інтенсивно йдуть процеси мінералізації органічних решток. Однак поряд з цим гумусоутворення, порівняно 3 чорноземом контролю, де надходить значно менше органічних решток, тут протікають досить інтенсивно. Враховуючи середньосуглинковий гранулометричний склад досліджуваного чорнозему можливо передбачити деяке переміщення новоутворених рухомих органічних речовин вниз по профілю грунту. Про це свідчать результати наших досліджень, які показують збільшення абсолютного вмісту рухомих органічних речовин у 2,3-2,6 рази порівняно з чорноземом контролю відповідно в шарах грунту 10-20 і 20-30 см. Також слід мати на увазі, що в умовах органічної системи удобрення урожайність вирощуваних культур значно вище, відповідно і загальна біопродуктивність вища.

Уміст рухомих органічних речовин у чорноземах типових за різних систем удобрень, \%

\begin{tabular}{|c|c|c|c|c|c|c|}
\hline \multirow[b]{2}{*}{ глибина, см } & \multicolumn{3}{|c|}{ Без добрив } & \multicolumn{3}{|c|}{ Система удобрення } \\
\hline & 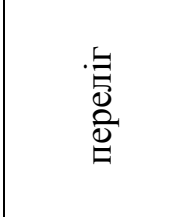 & 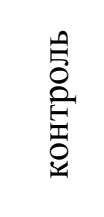 & 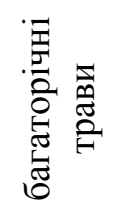 & 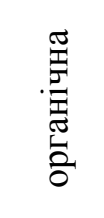 & 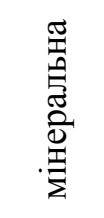 & 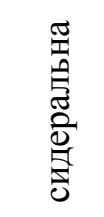 \\
\hline $0-10$ & $\underline{0,36^{\mathrm{x}}} 400,3$ & $\frac{0,09}{100,0}$ & $\frac{0,10}{111,3}$ & $\frac{0,19}{211,2}$ & $\frac{0,07}{77,1}$ & $\frac{0,17}{188,7}$ \\
\hline $10-20$ & $\frac{0,14}{280,2}$ & $\frac{0,05}{100,0}$ & $\frac{0,07}{140,2}$ & $\frac{0,13}{260,6}$ & $\frac{0,03}{60,6}$ & $\frac{0,10}{200,2}$ \\
\hline $20-30$ & $\frac{0,12}{400,5}$ & $\frac{0,03}{100,0}$ & $\frac{0,05}{166,6}$ & $\frac{0,07}{233,5}$ & $\frac{0,03}{100,0}$ & $\frac{0,05}{166,6}$ \\
\hline $30-40$ & $\frac{0,09}{300,6}$ & $\frac{0,03}{100,0}$ & $\frac{0,03}{100,0}$ & $\frac{0,03}{100,0}$ & $\frac{0,02}{66,6}$ & $\frac{0,05}{166,6}$ \\
\hline $40-50$ & $\frac{0,05}{250,1}$ & $\frac{0,02}{100,0}$ & $\frac{0,07}{350,4}$ & $\frac{0,05}{250,5}$ & $\frac{0,03}{150,6}$ & $\frac{0,03}{150,5}$ \\
\hline
\end{tabular}

$\mathrm{HIP}_{05}$ 0,01

Примітка: х - над рискою вміст, \%; під рискою \% до контролю 


\section{СІЛЬСЬКЕ ГОСПОДАРСТВО. РОСЛИННИЦТВО}

Тому у грунті залишається більше кореневих решток, які $є$ джерелом утворення рухомих органічних речовин. Близька до вказаної залежності тенденція спостерігається й у разі сидеральної системи удобрення (див. табл.).

Порівняно 3 контролем чорнозем за сидеральної системи удобрення містить в 1,5-2 рази більше органічних речовин. Це дещо менше, ніж за органічної системи удобрення. Але загальна закономірність деякого зростання вмісту рухомих органічних речовин у шарі 10-20 см і поступового його зниження вниз по профілю грунту тут також зберігається.

Особливий вплив на вміст рухомих органічних речовин має мінеральна система удобрення. На відміну від усіх досліджуваних варіантів, чорнозем за мінеральної системи удобрення характеризується найнижчим умістом рухомих органічних речовин. Особливо це стосується верхнього 20-сантиметрового шару грунту, де вміст рухомих органічних речовин становить усього $77 \%$ і 60 \% відносно контролю відповідно у шаpax 0-10 i 10-20 см. У шарі грунту 20-30 см спостерігається деяке зростання вмісту рухомих органічних речовин, але воно не перевищує значень варіанту контролю. Причину цього ми вбачаємо в певній диспергуючій дії мінеральних добрив відносно гумусових речовин грунту. Згідно 3 дослідженнями В. І. Філона [7] мінеральні добрива здатні викликати певну диспергуючу дію відносно гумусових речовин. Тому, враховуючи середньосуглинковий гранулометричний склад досліджуваних чорноземів, можливо пе- редбачити деяке переміщення рухомих органічних речовин з 0-20-сантиметрового шару в 2030-сантиметровий шар.

Гарним показником інтенсивності процесів гуміфікації в досліджуваних чорноземах є частка рухомих органічних речовин у загальному гумуci. Як показали розрахунки (див. рис.), найвища частка рухомих органічних речовин притаманна органічній частині чорнозему перелогу.

Сільськогосподарське використання чорноземів типових без застосування добрив (контроль) викликає суттєве зниження частки рухомих органічних речовин у складі загального гумусу грунту.

Застосування органічної і сидеральної систем удобрення сприяє суттєвому зростанню частки рухомих органічних речовин у загальному гумуci, особливо у верхньому 0-10-сантиметровому шарі чорнозему, порівняно із грунтом контролю.

Позитивний вплив на частку рухомих органічних речовин у загальному гумусі має введення у сівозміну трьохрічної культури багаторічних трав. Але цей вплив значно поступається органічній і сидеральній системам удобрення.

Мінеральна система удобрення значно поступається органічній і сидеральним системам за своїм впливом на частку рухомих органічних речовин у загальному гумусі.

Розрахунки показують, що за мінеральної системи удобрення частка рухомих органічних речовин навіть дещо поступається значенням цього показника в чорноземі контролю.

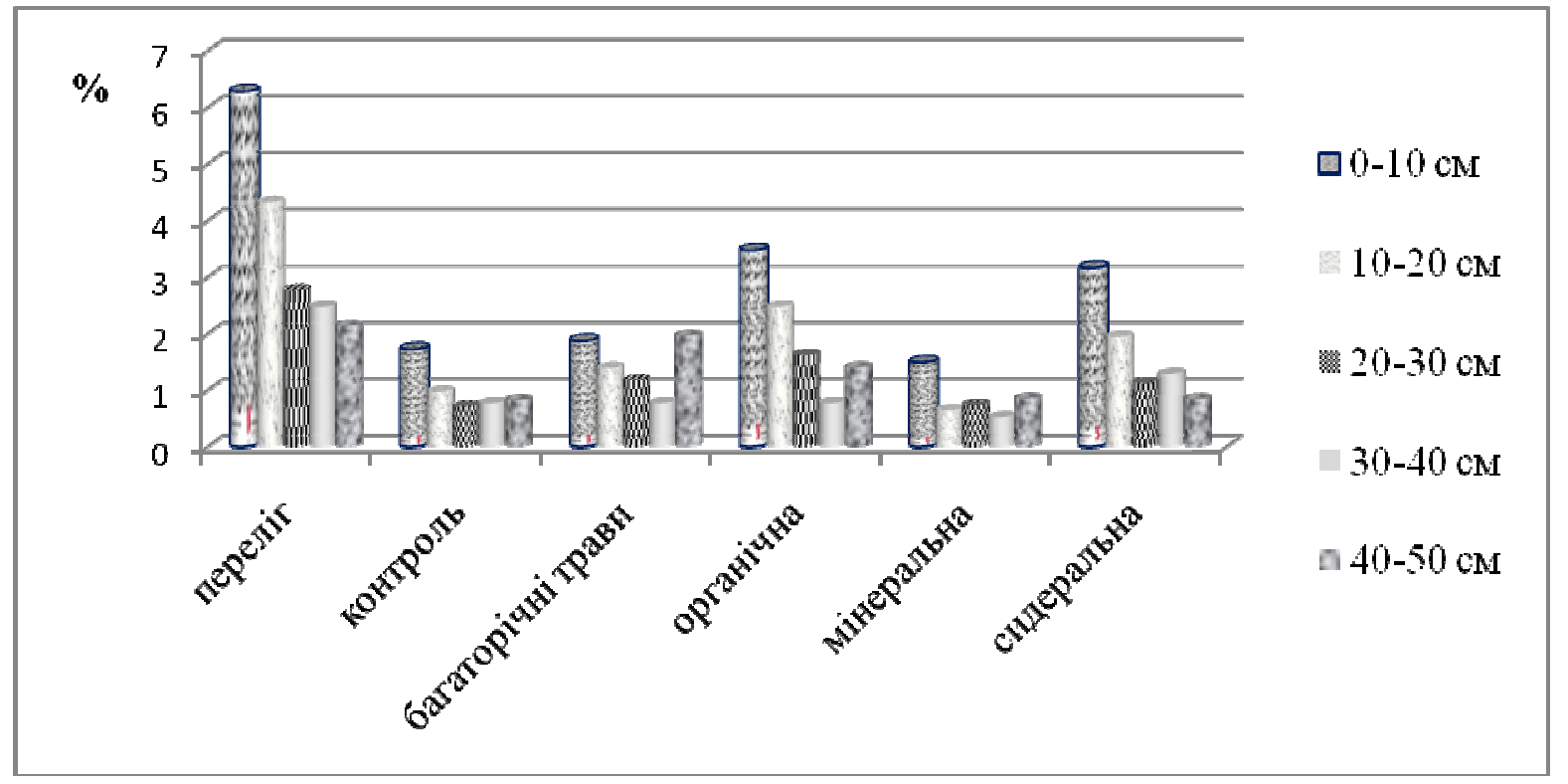

Рис. Частка рухомих органічних речовин у загальному тумусі чорноземів типових за різних систем удобрень, \% 
Таким чином, проведені дослідження показали позитивний вплив органічної і сидеральної систем удобрення на вміст рухомих органічних речовин у чорноземі типовому.

Застосування мінеральної системи удобрення викликає збіднення грунту на рухомі органічні речовини.

Висновок. Найвища частка рухомих органічних речовин притаманна органічній частині чор-

\section{БІБЛІОГРАФІЯ}

1. Алешин С. Н. К вопросу об изменении органического вещества почвы при длительном применении удобрений / С.Н.Алешин, Л.К. Шевцова, В. А. Черников // Агрохимия. - 1971. - №6. C. 49-54.

2. Дегтярьов В. В. Гумус чорноземів Лісостепу і Степу України / В. В. Дегтярьов ; за ред. д-ра. с.-г. наук, проф. Д. Г. Тихоненка / Харк. нац. аграр. ун. ім. В. В. Докучаєва. - Х. : Майдан, 2011. $-360 \mathrm{c}$.

3. Егоров М. А. Подвижное органическое вещество почвы как один из показателей окультуренности ее / Зап. Харьк. с.-Х. ин-т. - 1938. Вып.2. - Т.1. - С. 3-36.

4. Кауричев И. С. Проблемы гумуса пахотных почв при интенсивном земледелии / И. С. Кауричев // Почвоведение. - 1979. - №12. - С. 5-15.

5. Лактионов Н. И. Влияние распахивания на качественные изменения активного гумуса черноземов Украины / Н. И Лактионов, В.В.Дегтя- нозему перелогу.

Застосування органічної, сидеральної систем удобрення, а також уведення у сівозміну багаторічних трав сприяє надходженню значної маси органічних решток, що в кінцевому рахунку позитивно відбивається на інтенсивності процесів гуміфікації, накопиченню у грунті новоутворених рухомих органічних речовин.

рев // Тез. докл. II сьезда почвоведов и агрохимиков УССР. - Х. : 1986. - С. 34-35.

6. Льлков А. М. Оценка гумуса почв по характеристике его лабильной части / А. М. Лыков, В. А. Черников, Б. П. Боинган // Изв. ТСХА. - М. : 1981. - Вып.5. - С.65-70.

7. Філон В. I. Взаємодія мінеральних добрив 3 грунтом / В. І. Філон // Вісник аграрної науки. 2009. - №7. - C. 19-21.

8. Чесняк О. Л. Содержание подвижных органических веществ в черноземах мощных Лесостепи УССР как показатель окультуренности / О. Л. Чесняк, Г. Я. Чесняк，А. Я. Степаненко // Исследование плодородия почв УССР / Тр. Харьк. с.-Х. ин-т. - Х., 1970. - Т. 87/124. - С. 29-36.

9. Шевиова Л. К. Методы исследования органического вещества длительно удобряемых почв / Л. К. Шевцова // Почвоведение, 1972. - №8. C. $45-55$. 